\title{
Implementation of an individual educational route in inclusive practice
}

\author{
Oksana Titova $^{{ }^{*}}$, Margarita Bratkova $^{1}$, Olga Karanevskaya $^{1}$, Elena Gravitskaya ${ }^{1}$, and Irma \\ Barbakadze $^{2}$ \\ ${ }^{1}$ Moscow City University, Institute of Special Education and Psychology, Department of Special \\ Pedagogy and Comprehensive Rehabilitation, Moscow, Russia \\ ${ }^{2}$ East European University, Faculty of Business and Engineering, Tbilisi, Georgia
}

\begin{abstract}
There is currently a trend towards an increase in the number of children with special educational needs enrolled in inclusive schools. Thus, the number of children with special educational needs enrolled in inclusive schools is growing. This is caused both by significant changes in the legal regulatory framework, including the 2012 Federal Law on Education, the adoption of the Federal State Educational Standard of Primary General Education for Children with Special Needs, etc. and by the fact that in some regions the number of specialized schools is decreasing, inclusive education becomes a more affordable option for children with special education needs. School specialists, parents, and the public engage in an active dialogue about choosing the most efficient path for an educational route for special needs children, comparing the advantages and disadvantages of inclusive and special education. The design and implementation of an individual educational route, an individual curriculum is essential for children with special needs in terms of improving the quality of education and efficiently entering social life. The relevance of the study is determined by identifying the components that facilitate and complicate, hinder the development and implementation of an individual educational route for these children in an educational organization; the determination of the content of an individual educational route based on the current situation in a practical institution considering the requirements of inclusive education. The purpose of the study is to explore the problems of developing and implementing individual educational routes for children with special needs in the context of inclusion and to determine ways to solve these problems. The key methods of the study are a questionnaire and a structured interview. The empirical data confirms the assumption that the development and implementation of an individual educational route for children with special needs in an educational organization are problematic and inefficient for several reasons. The data obtained is new since similar research results have not been found in the open sources over the past five years.
\end{abstract}

Keywords: inclusive education, children with special needs, individual curriculum, special educational needs.

\footnotetext{
*Corresponding author: titovaov@mgpu.ru
} 


\section{Introduction}

The modern educational paradigm implements the right of children with special needs to quality education among normally developing peers (inclusion).

Discussion of the methodology, advantages and disadvantages of inclusive education, ways to improve the quality of education for children with special needs from the standpoint of specialists and parents are reflected in some publications in Russia (N.M. Nazarova, I.M. Yakovleva) and abroad [1-5]. At the same time, special attention is paid to the problem of mastering social skills both at the stage of preschool and school education as the most important condition for the socialization of a child with special educational needs [6-7].

Individualization and differentiation of education are important principles of special needs pedagogy and psychology [8]. For mainstream education, the consideration for the child's characteristics and capabilities becomes an integral part of the efficiency of education.

An individual educational route (IER) is the only possible condition for efficient education for children with special needs when traditional, widespread learning technologies cannot be applied.

The concept of IER is based on the development of an individual curriculum aimed at helping a child in the realization of their characteristics, self-actualization, and personal potential. When designing and implementing IER particular importance is given to determining the starting level of the child's development (comprehensive diagnostics) and teamwork [9]. Specialists developing IER for children with special needs start to experience difficulties and problems already during the development of IER and then during its implementation. This is due to the low availability of regulatory and scientificmethodological frameworks.

In practice, there are problems with considering the individual developmental characteristics of a child with special needs in a mainstream class; the sufficient training of teachers in mainstream schools; support of the IER by specialists at the medical, psychological, and pedagogical level; involvement of parents, etc. [10].

The modern school is aimed at the child's achievement of an academic result when individual capabilities and needs are not so significant. Meanwhile, there is no focus on socialization which is the main goal of teaching children with special needs. Researchers say that teachers of general education classes experience enormous difficulties in teaching children with atypical development [11-13]. There was a study that showed what steps needed to be taken to train specialists for inclusive education, including work on the valuesemantic preparedness of teachers [14-15].

These problems are a powerful factor hindering the efficient development and implementation of IER.

Hypothesis. Today, an IER in inclusive education is formally developed and complies with regulatory documents. However, it is necessary to increase the efficiency of the implementation of IER for children with special needs which will ensure the quality of their education.

The goals of the study: to develop questionnaires to assess the efficiency of development and implementation of IER into the practice of educational complexes; analyze empirical data; to assess the efficiency of the implemented IER.

\section{Methods}

The following methods were applied in this study:

a)theoretical - analysis of Russian and foreign literary sources,

b)empirical - conduct an establishing study using the original questionnaire that features the following parameters: "Number of students including those with special needs or 
disabilities", "Number of specialists from the psychological and pedagogical support service", "IER" and a questionnaire for parents on the implementation of IER and the efficiency of education for their children with special needs in educational organizations.

The information was processed using the Microsoft Office Excel software (Excel).

\section{Results}

Analysis of the results of the first block. The total number of students in educational complexes is 10,190 people, of which 3,887 children are students of preschool organizations. There are 2,881 children in primary education and 3,422 children in general education (Fig. 1). The total number of children with special needs is 1,072 . This is $10.5 \%$ of all students, that is, approximately every tenth child in an educational organization has a special needs status. There are 643 children with a disability status $-60 \%$ of the total number of students with special needs. Distribution of children with special needs: at the stage of preschool education, special needs children are $10 \%$ of the total number of schoolchildren, at the stage of primary education $-11 \%$, at the general stage $-8 \%$.

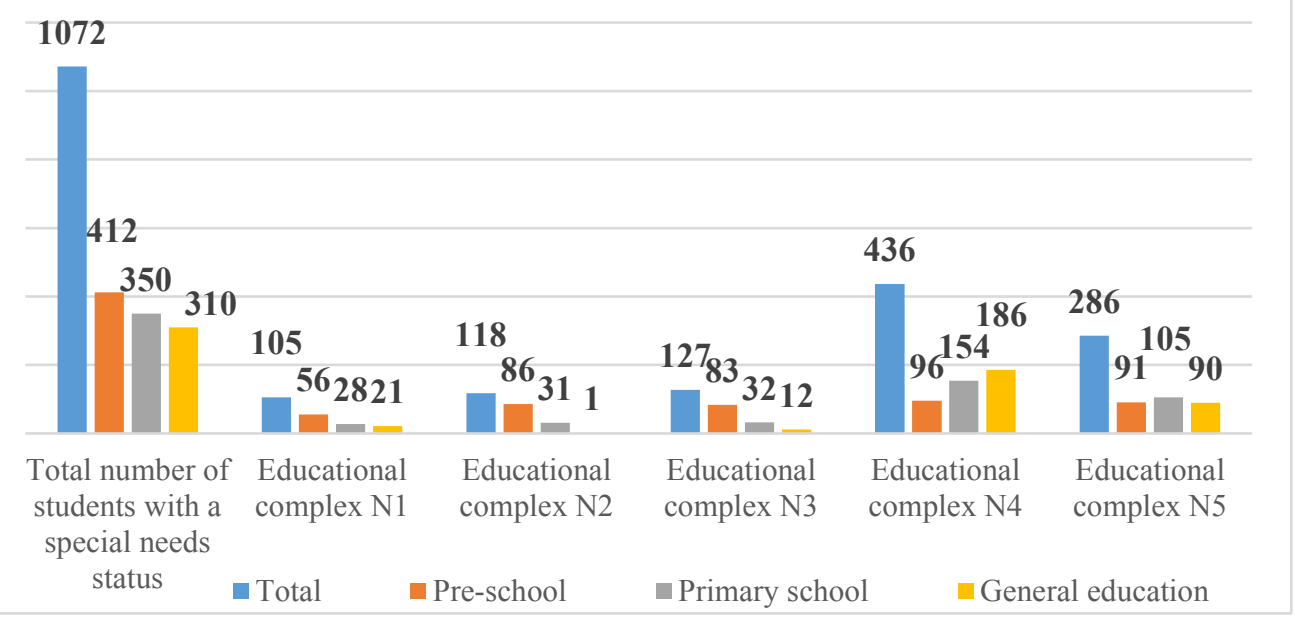

Fig. 1. The number of students with a special needs status.

Analysis of the results showed that $1 \%$ were children with hearing disabilities, $7 \%$ with vision impairments, $11 \%$ with severe multiple impairments, $23 \%$ with musculoskeletal disorders, $27 \%$ with developmental disabilities, $30 \%$ with autism spectrum disorders, $32 \%$ with intellectual disabilities, and 69\% with speech disorders.

The second block was aimed at studying the composition and number of specialists who were part of the team for supporting students with special needs in inclusion. 


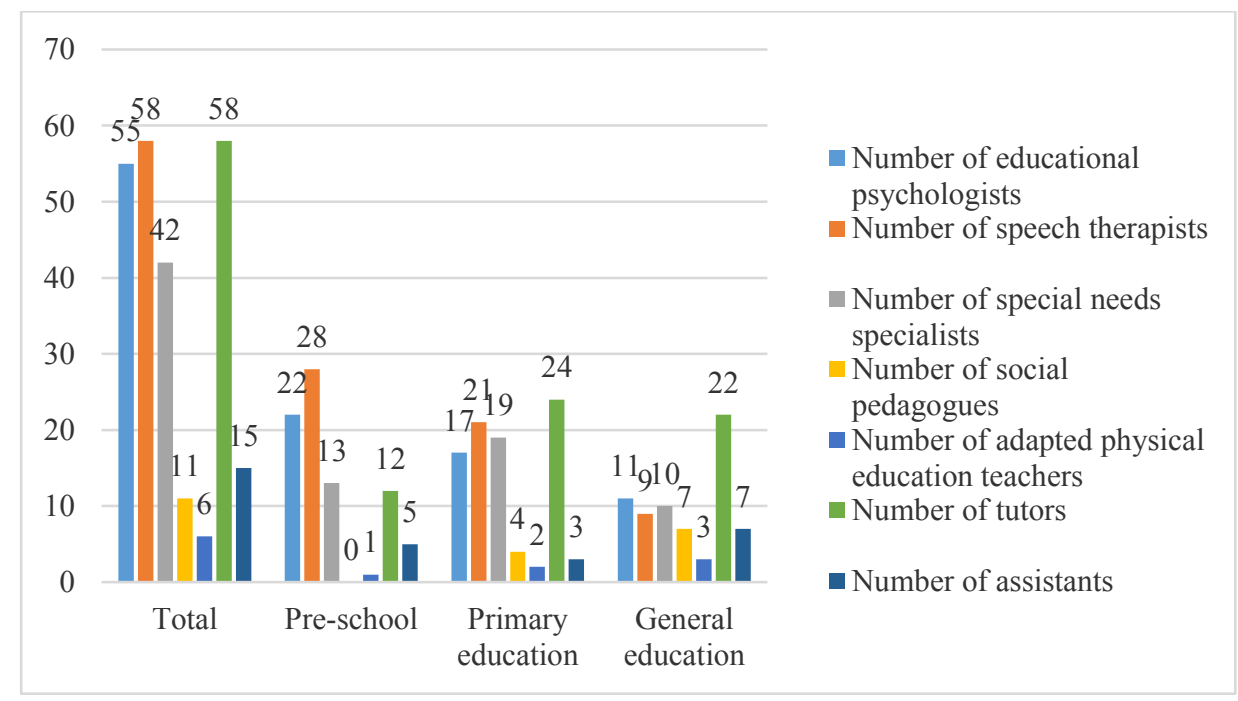

Fig. 2. Number of specialists.

The largest group of specialists consists of 58 speech therapists and tutors, 55 educational psychologists, 42 special needs specialists, 15 assistants, 11 social pedagogues, and six teachers of adapted physical education (Fig. 2).

Tutors accompany children with special needs at the school stage of education, at the preschool stage there are half as many of them. There are few assistants in educational organizations, and these specialists are distributed rather evenly between all stages of education. There is a shortage of adapted physical education instructors. Inclusive educational organizations do not use the resource of network interaction and do not invite specialists from outside organizations.

The third block is an analysis of the situation of administrative support for inclusive education. The positions of the head of inclusive department are included in the structure of three educational organizations. Two educational organizations do not have such positions in their organizational structures. Each educational complex has a psychological and pedagogical board. An IER is developed for each student with special needs.

At the second stage of the experiment, a survey was conducted for parents of children with special needs, to identify parents' knowledge about IER. Fifty parents participated in the survey. According to the survey, $57.9 \%$ of children with special needs study in inclusive schools and $42.1 \%$ in special educational institutions. Of these, $47.4 \%$ are in primary school, $26.3 \%$ in secondary school, and $26.3 \%$ in preschool education. The survey showed that $47.4 \%$ of parents only had a general idea of what an IER was while $42.1 \%$ were aware of IER. A lot of parents (84.2\%) noted that an IER has not been developed for their child, $47.4 \%$ of the respondents said that an adapted curriculum has been developed for their children, and $52.6 \%$ said there was no such curriculum. Out of all respondents, $84.2 \%$ of parents were not invited to a psychological and pedagogical board meeting in an educational organization, while $47.4 \%$ of parents had been part of the discussion about IER, the rest did not participate in this process. When asked about the availability of all specialists implementing IER, $57.9 \%$ of parents answered that not all were available. At the same time, $78.9 \%$ of respondents were partially satisfied with the quality of services provided, $15.8 \%$ were not satisfied. Moreover, $63.2 \%$ of parents did not regularly interact with specialists of the educational organization and only $21.1 \%$ did so constantly. When asked about considering children's individual characteristics in the educational process, $78.9 \%$ of parents answered that this was happening partially. Discussing the priority tasks of educating children with special needs, $57.9 \%$ of 
parents answered that those were only educational tasks, and the tasks of raising and socializing children with special needs were not being sufficiently addressed.

\section{Discussion}

The study has demonstrated the current situation of IER implementation for students with special needs. In all educational organizations, the experts from the board develop IER for students with special educational needs. At the same time, every tenth child in an educational organization has a special needs status confirmed by the Psychological Medical and Pedagogical Commission, and more than half of them are children with disabilities, which confirms the general trend of an increase in such children in educational organizations.

Most children have speech disorders and need speech therapy technologies, but there is also a group of children with intellectual disabilities and autism spectrum disorders who need corrective support from a special needs specialist, psychologist, and tutor. Most of the children have movement disorders which indicates the need to include an adapted physical education teacher. However, the analysis shows that there are not enough such specialists in the educational organization.

The success of the IER implementation is largely ensured by the involvement of the family in this process. According to the results of the study, most parents (84.2\%) said that their children do not have IER. Many parents (78.9\%) indicated that the individual characteristics of the development of their children were not considered in the learning process.

In many educational institutions, IER are developed formally and do not implement the main tasks in the process of education and supporting a child with special needs in the educational space, which is also confirmed by the parents' dissatisfaction with the efficiency of educational services.

The absence of a leader in inclusive education negatively affects the optimal organization of education for children with special needs in solving problem situations, the organization of interaction between the educational organization and parents. This is confirmed by $63.2 \%$ of parents.

The analysis of the number of specialists and dissatisfaction with the quality and amount of time of correctional and developmental work by parents allows one to conclude the problems of specialists supporting children with special needs in inclusive education.

Therefore, it is necessary to consider ways to overcome the identified problems during further education courses, conferences, round tables, etc. It is important to form an understanding among the pedagogical community about the need to implement teamwork with the obligatory inclusion of parents for efficient teaching of children with special needs.

\section{Conclusion}

It is significant to thoroughly study the mechanisms for introducing IER which is not formal: staff training, the inclusion of the necessary specialists in sufficient numbers, the organization of an accessible environment, the connection of the administrative resource that coordinates inclusive processes in educational organizations.

The study raises the problem of resolving existing stereotypes among teachers, when not only academic results become significant but also achievements in the field of socialization, self-expression, personal development of a child with special needs, which is impossible without the children's collective and family.

In conclusion, we note that the development and implementation of IER for children with special needs is a necessary and important component of modern education. The priority in 
the process of its implementation should be not a formal approach - the availability of documents supporting a child with disabilities in an inclusive space but a description of the organization and content of educational, correctional, and developmental work aimed at preparing a child with special needs for an independent life in society, based on teamwork. At the same time, it is necessary to introduce a monitoring system for the implementation of IER to correct the educational route and achieve high-quality educational results.

\section{References}

1. A.M. Alhassan, Advances in Social Sciences Research Journal, 1(2), 115-129 (2014). https://doi.org/10.14738/assrj.12.124

2. G. de Graaf, G. van Hove, Life Span and Disability, 18(1), 7-39 (2015)

3. T. Kirjavainen, J. Pulkkinen, M. Jahnukainen, Learning and Individual Differences, 45, 33-42 (2016). https://doi.org/10.1016/j.lindif.2015.12.001

4. C.R. Baptista, Educ. Pesqui., São Paulo, 45, e217423 (2019). http://dx.doi.org/10.1590/S1678-4634201945217423

5. T.M. Makoelle, Exceptional children, 67(4), 467-484 (2020). https://doi.org/10.1177/001440290106700403

6. G. Bossaert, A.A. de Boer, P. Frostad, S.J. Pijl, K. Petry, Irish Educational Studies, 34(1), 43-54 (2015). http://doi.org/10.1080/03323315.2015.1010703

7. T. Hall, Sage Open, 10(1), 1-13 (2020). https://doi.org/10.1177/2158244019899420

8. V.V. Voronkova, Differentsirovannyy podkhod v korrektsionno-razvivayushchem obuchenii russkomu yazyku umstvenno otstalykh shkol'nikov I-IV klassov [Differentiated approach to special teaching of the Russian language to schoolchildren with intellectual disability in year 1-4], Thesis (Institute for Advanced Studies and Retraining of Public Education Workers of the Moscow Region, Moscow, 2009)

9. M.V. Bratkova, O.V. Karanevskaya, O.V. Titova, Innovatsii v obrazovanii, 10, 19-26 (2013)

10. T.G. Bogdanova, A.M. Guseinova, N.M. Nazarova, Pedagogika inklyuzivnogo obrazovaniya [Pedagogy of inclusive education] (INFRA-M, Moscow, 2017)

11. S.V. Alekhina, Vestnik of Moscow City University. Series "Pedagogy and psychology", 4(22), 117-127 (2012)

12. A.G. Ryapisova, Vestnik Novosibirskogo gosudarstvennogo universiteta, 7(1), 7-20 (2017). http://doi.org/10.15293/2226-3365.1701.01

13. M.R. Khusnutdinova, Obrazovanie i nauka, 19(3), 26-46 (2017). http://doi.org/10.17853/1994-5639-2017-3-26-46

14. T.V. Safonova, A.S. Suntsova, R.G. Aslaeva, Integratsiya obrazovaniya, 23(1), 50-65 (2019). https://doi.org/10.15507/1991- 9468.094.023.201901.050-065

15. I.M. Yakovleva, Vestnik MGOPU, Series “Pedagogy”, 4, 140-144 (2009) 